\title{
FDI, Stock Market Development and Institutional Quality: An African Perspective
}

\author{
Patricia Lindelwa Makoni ${ }^{1}$ \\ ${ }^{1}$ University of South Africa (UNISA), Department of Finance, Risk Management and Banking, South Africa \\ Correspondence: Patricia Makoni, University of South Africa (UNISA), Department of Finance, Risk Management \\ and Banking, South Africa. Tel: 27-76-753-8234. E-mail: patricia.makoni@gmail.com, makonpl@unisa.ac.za
}

Received: June 24, 2021

Accepted: August 30, 2021

Online Published: September 6, 2021

doi:10.5430/ijfr.v12n5p141

URL: https://doi.org/10.5430/ijfr.v12n5p141

\begin{abstract}
This paper empirically sought to establish the existence of relationships between foreign direct investment, stock market development and institutional quality, respectively. The study adopted a multiple regression analysis, using a panel of nine African countries between 2009 and 2016. Using the random effects model, we find that the relationship between foreign direct investment and stock market development is positive and statistically significant. On the other hand, institutional quality reflected a negative effect on FDI inflows, implying that countries with low quality institutions would struggle to attract inward FDI. The policy implications are that host countries' policy makers should eliminate or reduce any practices that deter foreign direct investments, such as capital controls and risk of expropriation (institutions), while simultaneously improving the domestic financial infrastructure and related regulations.
\end{abstract}

Keywords: FDI, stock market development, institutional quality, Africa

\section{Introduction}

International capital flows are comprised of foreign direct investment (FDI), foreign portfolio investment (FPI), foreign aid and foreign debt. The past decade has seen international capital flows being channelled from developed to developing countries due to the presence of mineral wealth, reliable infrastructure, a large pool of semi-skilled, cheap labour, amongst other attractions (De Santis \& Ehling, 2007; Sarno, Tsiakas \& Ulloa, 2016). Recently however, the COVID-19 pandemic resulted in a global shut down of many financial markets and slow down of economic activity across the world, as investors adopted a cautious wait-and-see approach on their projects, resulting in many developing countries losing out on potential inward capital flows (OECD, 2021). According to the UNCTAD's World Investment Report (WIR, 2021), global FDI flows decreased to approximately USD1 trillion in 2020 from USD1.5 trillion, reflecting a decline of $35 \%$ compared to 2019. Although developing countries are making a concerted effort to wean themselves of foreign aid assistance, and foreign debt that they need to pay back from their limited foreign currency reserves, often negatively affecting their fiscus; many still struggle to attract adequate permanent foreign capital flows in the form of FDI to complement their domestic savings and investments. Without adequate financial capital, many large-scale investment projects are halted, as the available funding cannot sustain the required productivity levels to boost economic growth.

Multinational corporations' (MNCs) engage in foreign direct investment activities for various reasons. As affirmed by Hymer (1960), the determinant factors as to 'where' to locate such investments is guided by a number of considerations. It is however Dunning's (1977) seminal work that underpinned the importance to MNCs of the ownership, locational and internalisation (OLI) variables of the eclectic paradigm. Of these factors, this paper is concerned with the locational determinants of financial market development, focusing specifically on the role of stock market development and institutional quality, respectively, in the host country.

Host country stock market development is a situation whereby a country is able to collect, receive, and allocate savings and investments to productive economic sectors, efficiently and effectively within its borders. This is achievable because of the financial markets' size, liquidity, performance, financial asset offerings, as well as the institutional and regulatory framework in the host country (Dorrucci, Meyer-Cirkel \& Santabárbara, 2009; World Economic Forum, 2012). Most existing empirical studies focused on FDI determinants that enhance a host country's attractiveness to FDI such as market size (GDP), economic growth rate, infrastructural development, natural 
resources endowment, stability of the exchange rate, among others (Asiedu, 2006; Bokpin, Mensah \& Asamoah, 2015; Makoni, 2020), while ignoring the growing importance of the complementarity between capital markets and institutions.

The spill-over effects of increased FDI inflows are an additional source of capital, resuscitation of ailing industrial sectors and companies, introduction and transfer of new technology that improves production, skilled labour from abroad, increasing levels of economic growth, reduction of unemployment, financial market development, and access to global markets (Haque, Patnaik \& Hashmi, 2017; Agbloyor, Abor, Adjasi \& Yawson, 2013; Alfaro, Chanda, Kalemli-Ozcan \& Sayek, 2004). Despite these positive potentials of FDI, governments remain cautious and maintain macro-economic policies that will not crowd out domestic savings and investment, while also protecting domestic corporations from being pushed out of the competitive market, ensuring the non-exploitation lowly-skilled labour and exhaustion of natural resources by MNCs.

It is against this backdrop that this paper aims to assess the interrelationships between FDI, stock market development and institutional quality for selected developing Africa countries. Although FDI does not necessarily target stock markets, MNCs do eventually use it as a financial management strategy to raise further capital to fund their local projects. Developed financial markets, coupled with strong institutional quality, are regarded as an important, but under-studied phenomenon as far as FDI is concerned. This paper contributes to the existing scholarly debates on international finance in two ways: firstly, the study jointly assesses the determinants of foreign direct investment, with particular interest in the role played by stock market development (SMD), as well as the quality of institutions in selected African economies. Secondly, by using the Kuncic (2014) database of institutional quality variables, this paper provides a basis for future comparative studies gauged between the World Bank's governance indicators and the findings of this study. This paper is motivated by the limited and scant empirical research work on the FDI-stock market development-institutional quality nexus from a developing country cluster perspective. The focus on African countries is deliberate, and this research may highlight key policy implications for policy for consideration.

The remainder of this paper is structured as follows: Section 2 provides the relevant literature review; Section 3 presents the data, study variables and the methodology adopted. The empirical results are presented and discussed in section 4, while section 5 concludes the paper.

\section{Literature Review}

Several scholars have attempted to theoretically and empirically explain the nature and behaviour of foreign direct investment, from both the macroeconomic and microeconomic perspectives. According to Makoni (2016), FDI theory can be traced back to various underpinnings such as the theories of international specialisation of production, international capital markets, and international trade. Makoni (2016) further asserted that developed and well-functioning financial markets, such as domestic stock and bank credit markets, are a key feature in the MNCs' investment decision-making process, because they affect the economic and financial decisions, and transactions of FDI projects. In addition, the role of a country's institutions and institutional quality is central to FDI decisions and commitments by MNCs. Institutional quality reflects the state of legal, political, economic and regulatory institutions in the host country, which influences its attractiveness to foreign and domestic investment. This can be in the form of sound corporate governance, provision of assurances against expropriation, enforcement of contracts and financial market regulation. MNCs will generally disinvestment and redirect their foreign investments to other countries if any of the socio-cultural, education, market and institutional quality variables appear to be rigid in the host country. This is because potential host countries' economic and political instability pose a threat to FDI investments (Wilhelms \& Witter, 1998). Although all four pillars are central to FDI decisions, this study is only interested in the government (institutions) and (stock) market factors.

Schumpeter (1912), Goldsmith (1969), McKinnon (1973) and Shaw (1973), hypothesised that financial sector development affects the allocation of savings, improves productivity and technological growth, and hence improves economic growth. Previous studies have tested these hypotheses and concluded that host countries with well-developed stock markets, augmented by macroeconomic stability, investor-friendly policies and strong institutions, stand a better chance of being recipients of foreign direct investment (FDI) (Sawalha, Elian \& Suliman, 2016; Hajilee \& Nasser, 2015; Yartey, 2010).

FDI brings in much-needed foreign currency, is crucial to build up currency reserves, as well as balance of payments international commitments (Bekaert \& Harvey, 2000). Humanicki, Kelm and Olszewski (2017) contend that foreign direct investors play a pivotal role in emerging markets. One of the advantages of foreign direct investment is that it enhances capital inflows in developing economies, and in the process, improves liquidity and efficiency of host 
countries' stock markets.

North (1990) attested that developed, efficient stock markets complemented by good institutional quality dictate the rules of the game, by enabling reduced transaction and information costs. Integrated stock markets present investors with the opportunity to pursue objectives of portfolio diversification and possibly higher returns on investment, based on available information, on other countries' markets. The positive relationship between foreign direct investment and stock market development was found in various earlier empirical studies. Soumaré and Tchana Tchana (2015) concluded bi-directional causality between FDI and stock market development in their study on 29 emerging market countries from 1994 to 2006. Similarly, Hajilee and Nasser (2015) examined the impact of financial market development on FDI in 14 Latin American countries, concluding that there is uni-directional causality between FDI and the banking sector, but bi-directional causality between FDI and stock market development. The latter finding confirms complementarity between FDI and domestic stock markets of host countries. Kharabsheh and Aldaher (2020) examined causality between FDI and financial market development in Jordan between 1978 and 2017, using an array of econometric tests and variables. They found that, in the short run, there is a positive and significant relationship between FDI and stock market development (SMD), a long run cointegrating relationship between FDI and financial market development, and uni-directional causality between SMD and FDI. Islam, Khan, Popp, Sroka and Oláh (2020) assessed the moderating role played by institutional quality on financial market development and FDI. Their empirical findings revealed that financial market development has a positive and significant effect on foreign direct investment. Further, in the context of the financial market development-foreign direct investment nexus, the moderation effect of financial market development and institutional quality was established to be highly significant. Despite these earlier empirical studies, there remains evidence of a knowledge gap and insufficient documented evidence on the relationship between stock market development and foreign direct investment, as contrasting results have been previously reported. The existing FDI literature has been largely biased towards the level of financial market development of the destination host country, ignoring other determinant factors such as institutional quality.

Institutional variables are considered to be those factors which potentially create the inefficiencies of stock markets, and therefore increase the monitoring and costs of capital for both domestic firms and multinational corporations, as well as uncertainty of return on investments (capital gains and dividends) (Grosse \& Trevino, 1996; Jensen, 2003). The relationship between FDI and institutional quality has been found to be positive in the studies by Stein and Daude (2001), Globerman and Shapiro (2003) and Bailey (2018). This was attributed to a lower expropriation risk, enforcement of contracts, and respect for property rights by the host countries. It is therefore highly probable that countries with better institutional quality will attract FDI inflows. Asiedu (2013) affirmed that as long as quality institutions are absent in developing countries, natural resources endowment may not necessarily be relied on to attract inward FDI. Due to the inconsistency of findings in earlier empirical studies, mostly conducted in developed countries, we wish to add to the existing international finance literature by further examining the relationships between FDI, stock market development and institutional quality in selected developing African countries, between the period 2009 and 2016.

\section{Data, Variables and Methodology}

The primary objective of this study was to examine the relationships between foreign direct investment, stock market development and institutional quality. This paper considers a small sample of African countries that we deemed to be integrated with the global markets, and would thus be representative of developing countries on the continent. As such, the countries for which we used panel data extracted from the World Bank's World Development Indicators' (WDI) database were Botswana, Cote D'Ivoire, Egypt, Ghana, Kenya, Mauritius, Morocco, Nigeria, and South Africa. The period of study was from 2009 to 2016. These countries were selected because of their advanced stock markets, and availability of complete data for the period under review.

In determining the relationship between FDI, stock market development and institutional quality, we estimated the following model:

$$
\begin{aligned}
F D I_{i t}= & \alpha_{0} F D I_{i t-1}+\alpha_{1} S M D_{i t}+\alpha_{2} I N S T Q_{i t}+\alpha_{3} R G D P G_{i t}+\alpha_{4} I N F L_{i t}+\alpha_{5} I N T R_{i t}+\alpha_{6} G O V S P_{i t}+ \\
& \alpha_{7} \text { TRDOPN }_{i t}+\alpha_{8} \text { KAOPEN }_{i t}+\alpha_{9} \text { REXCR }_{i t}+\varepsilon_{i t}
\end{aligned}
$$

Where, FDI is measured as the ratio of net FDI to GDP. Net FDI inflows measure the net inflows of investment from outside the country, made with the intention to acquire a lasting management interest of $10 \%$ or more of the voting share in a firm operating in an economy other than the home country of the investor. The independent variables are stock market development (SMD) and institutional quality (INSTQ). Stock market development, proxied by stock 
market capitalisation as a share of GDP (SMCAP), serves to measure two aspects: the size of the domestic equity market, as well as financial market depth. SMCAP evaluates the size of the stock market, relative to its economy. INSTQ represents legal, political and economic institutional quality proxied as a composite index of over 30 variables derived from the Kuncic (2014) database.

The control variables for this study included: the real annual GDP growth rate (RGDPG), rate of inflation (INFL), interest rates (INTR), the real exchange rate (REXCR), government spending (GOVSP), trade openness (TRDOPN), and capital openness (KAOPEN). The first four variables measure macroeconomic stability in a country, while trade openness and capital openness determine the restrictions imposed on imports and exports, as well as the free movement of money in and out of the host countries. Government spending is the investment made by the public sector, for the purchase and provision of public goods and services. We also captured the one period lag of FDI as a proxy for the persistence and dynamic characteristic of present day FDI inflows. $i$ denotes country, $t$ denotes time, $\alpha_{0}$ is a constant term, and $\varepsilon_{i t}$ is a random error term.. These variables were identified from the review of earlier theoretical and empirical literature. Data was sourced from the World Bank's WDI database, except the institutional quality variable, which was obtained from the Kunčič database.

Before regressing our data using the above econometric model, diagnostic tests were run. In order to circumvent the likelihood of spurious results emanating from the regression analysis, the data was tested for serial correlation, multicollinearity and heteroskedasticity. The Ordinary Least Squares (OLS) model was applied to the multiple regression to determine the nature of the relationship between the dependent FDI variable, and its independent variables. The next section presents the results of the regression analysis.

\section{Empirical Findings and Discussions}

The estimation results are presented in this section. Although multiple regression analysis suffers from multicollinearity, we tested our variables using a correlation matrix. At the 5\% level of significance, none of the results returned any high correlations between the variables under study; hence, it can be concluded that multicollinearity is not present in this panel data set.

A number of estimation techniques were adopted in this study. Table 1 below presents our estimation results. The one-period lag of foreign direct investment (FDI) was included in the regression to control for dynamic effects.

Table 1. Estimation results

\begin{tabular}{|c|c|c|c|c|c|c|}
\hline & $\begin{array}{c}\text { OLS } \\
\text { ROBUST }\end{array}$ & $\begin{array}{c}\text { FIXED } \\
\text { EFFECTS }\end{array}$ & $\begin{array}{l}\text { RANDOM } \\
\text { EFFECTS }\end{array}$ & $\begin{array}{c}\text { 2-STEP } \\
\text { GMM }\end{array}$ & GLS & LSDVC \\
\hline L.FDIGDP & $\begin{array}{c}0.00286 \\
(0.194)\end{array}$ & $\begin{array}{c}-0.0894 \\
(0.0818)\end{array}$ & $\begin{array}{l}0.00286 \\
(0.0791)\end{array}$ & $\begin{array}{l}-0.872 \\
(0.546)\end{array}$ & $\begin{array}{l}-0.0198 \\
(0.0228)\end{array}$ & $\begin{array}{l}0.0668 \\
(0.391)\end{array}$ \\
\hline SMCAP & $\begin{array}{c}0.266 \\
(0.215)\end{array}$ & $\begin{array}{c}0.420 \\
(0.561)\end{array}$ & $\begin{array}{l}0.266^{* * *} \\
(0.0795)\end{array}$ & $\begin{array}{c}1.844 \\
(2.594)\end{array}$ & $\begin{array}{l}0.242^{* * *} \\
(0.0173)\end{array}$ & $\begin{array}{l}0.454^{* * *} \\
(0.0142)\end{array}$ \\
\hline INSTQ & $\begin{array}{l}-53.53 \\
(43.64)\end{array}$ & $\begin{array}{l}-98.80 \\
(100.6)\end{array}$ & $\begin{array}{l}-53.53 \\
(65.94)\end{array}$ & $\begin{array}{l}-80.71 \\
(72.31)\end{array}$ & $\begin{array}{l}-24.99^{* *} \\
(8.158)\end{array}$ & $\begin{array}{c}-98.67^{* *} \\
(30.49)\end{array}$ \\
\hline RGDPG & $\begin{array}{c}0.620 \\
(0.664)\end{array}$ & $\begin{array}{l}-0.665 \\
(1.896)\end{array}$ & $\begin{array}{c}0.620 \\
(0.560)\end{array}$ & $\begin{array}{c}2.975 \\
(24.65)\end{array}$ & $\begin{array}{l}0.644^{* * *} \\
(0.0962)\end{array}$ & $\begin{array}{l}-0.629 \\
(3.081)\end{array}$ \\
\hline REXCR & $\begin{array}{l}-0.0426 \\
(0.0340)\end{array}$ & $\begin{array}{l}-0.334 \\
(0.607)\end{array}$ & $\begin{array}{l}-0.0426^{*} \\
(0.0180)\end{array}$ & $\begin{array}{c}1.223 \\
(3.263)\end{array}$ & $\begin{array}{l}-0.0520^{* *} \\
(0.0180)\end{array}$ & $\begin{array}{l}-0.368 \\
(1.707)\end{array}$ \\
\hline INFL & $\begin{array}{l}-0.0441 \\
(0.0923)\end{array}$ & $\begin{array}{c}0.246 \\
(0.252)\end{array}$ & $\begin{array}{l}-0.0441 \\
(0.118)\end{array}$ & $\begin{array}{l}-0.324 \\
(2.742)\end{array}$ & $\begin{array}{c}0.0261 \\
(0.0237)\end{array}$ & $\begin{array}{c}0.246 \\
(0.305)\end{array}$ \\
\hline
\end{tabular}




\begin{tabular}{lcccccc} 
INTR & -0.871 & -4.608 & -0.871 & -84.82 & -0.128 & -4.719 \\
& $(1.112)$ & $(4.955)$ & $(2.101)$ & $(116.9)$ & $(0.471)$ & $(6.726)$ \\
GOVSP & -4.249 & 7.685 & $-4.249^{* * *}$ & -4.088 & $-3.865^{* * *}$ & $7.753^{* *}$ \\
& $(3.390)$ & $(10.04)$ & $(1.103)$ & $(46.94)$ & $(0.160)$ & $(2.930)$ \\
& & & & & \\
TRDOPN & 0.446 & -1.238 & $0.446^{* * *}$ & 0.131 & $0.468^{* * *}$ & -1.265 \\
& $(0.366)$ & $(1.294)$ & $(0.103)$ & $(8.342)$ & $(0.0305)$ & $(1.376)$ \\
& & & & & $1.777^{* *}$ & 3.045 \\
KAOPEN & 3.593 & 3.841 & 3.593 & 0 & $(0.613)$ & $(7.720)$ \\
& $(3.219)$ & $(4.322)$ & $(4.026)$ & $(0)$ & & \\
\multirow{2}{*}{ cons } & 55.80 & 89.44 & 55.80 & & $28.68^{* *}$ & \\
& $(46.04)$ & $(111.1)$ & $(62.69)$ & & $(9.405)$ & 63 \\
\hline$N$ & 63 & 63 & 63 & 54 & 63 & \\
$R^{2}$ & 0.547 & 0.145 & & & & \\
\hline
\end{tabular}

Standard errors in parentheses; $* * *, * *, *$ Denotes $1 \%, 5 \%$ and $10 \%$ level of significance respectively

Source: Author's own computations

According to $\mathrm{Lu}$ and White (2014), robustness checks in empirical studies enable researchers to observe the behaviour of core regression coefficient estimates when the specified regression model is by either adding or removing regressors. This follows the earlier work of Leamer (1983) who asserted that it is necessary to undertake sensitivity analyses, also known as robustness checks, in order to accurately diagnose model misspecifications. As such, while the most common robustness test in finance and economics is the Hausman specification test, it is often supplemented by other diagnostic checks such as the pooled OLS, Fixed effects (FE) model, Random effects (RE) model, Generalized Method of Moments (GMM) model, the Generalized least squares (GLS) and the Least squares dummy variable (LSDV) corrected for Kiviet bias (see Kiviet, 1995). The use of multiple checks, mainly as a method for rigorous robustness testing, strengthens the validity and reliability of conclusions drawn from finance and economics empirical research. Table 2 below shows the diagnostic statistics of all the estimation models presented in Table 1 above.

Table 2. Diagnostic statistics

\begin{tabular}{lllllll}
\hline & OLS & FE & RE & 2-STEP GMM & GLS & LSDVC \\
\hline Observations & 63 & 63 & 63 & 54 & 63 & 63 \\
\hline Groups & 9 & 9 & 9 & 9 & 9 & 9 \\
\hline F-stats/Wald chi2 & 62.66 & 3528.90 & 2974.52 & 0.58 & 1946.73 & \\
\hline Prob>F/Prob>Wald chi2 & 0.0000 & 0.0000 & 0.0000 & 0.786 & 0.0000 \\
\hline Hausman (Chi2) & & 8.82 & 8.82 & & & \\
Prob>chi2 & & 0.5491 & 0.5491 & & & \\
\hline R-SQUARED & & & & & & \\
Within & & 0.1446 & 0.0212 & & & \\
Between & 0.0117 & 0.9061 & & & \\
Overall & 0.5465 & 0.0003 & 0.5465 & & -3.86 & \\
\hline Arellano-Bond AR(1) & & & & & &
\end{tabular}




\begin{tabular}{ll} 
Prob $>\mathrm{z}$ & 0.000 \\
\hline Arellano-Bond AR(2) & -1.18 \\
Prob $>\mathrm{z}$ & 0.238 \\
\hline Sargan test of overid & 34.72 \\
Prob $>$ chi2 & 0.000 \\
\hline Hansen test of overid & 1.39 \\
Prob $>$ chi2 & 0.868 \\
\hline Instruments & 41 \\
\hline
\end{tabular}

Source: Author's own computations

According to the post-estimation Arellano-Bond AR (1) and AR (2), the tests did not show any significant rejection of the null hypothesis that there is no first order and second order correlation in the estimated residuals; therefore, this paper's findings are consistent. The Hansen test with a p-value of 0.868 implies that the instruments used in the empirical estimation are appropriate. Further, as per the Hausman test results in Table 2 above, we fail to reject the null hypothesis, that the unobservable, country-specific effects and the regressors are statistically independent (orthogonal). Therefore, the random-effects estimation results are analysed and discussed herein.

Based on the random effects (RE) model, the estimation results show that there is a positive and significant relationship between foreign direct investment and stock market development in our sampled African countries. The highly significant (at 1\%) and positive sign, was expected in line with literature, as well as the level of development and integration of the selected stock markets in our countries of interest. This implies that the stock markets are steadily and continuously growing in recognition of their ability to receive, transform and allocate inward FDI flows to productive sectors of the economy. This finding is consistent with that of King and Levine (1993), Rajan and Zingales (1998) and Kurul (2017), who concluded that stock market development variables are correlated with increased capital and investment accumulation. In this instance, stock markets further act as an efficient conduit for capital allocation in the economy, as postulated by Schumpeter (1912). Foreign direct investors would therefore be attracted to countries that offer a low cost of capital and an opportunity to diversify their long-term investments, in order to be able to borrow abroad, as well as realize capital gains and strong dividend yields. Soumaré and Tchana Tchana (2015) and Donaubauer, Neumayer and Nunnekamp (2016) however found that there is in fact, bidirectional causality between FDI and stock market development, implying that the two variables are substitutes for one another.

The institutional quality measures the legal, political, economic, and bureaucratic characteristics of host countries. We expected a positive sign between FDI and institutional quality due to the efforts being made by host countries to be more receptive to inward FDI. However, the findings of this study determined that there is a negative relationship between FDI and institutional quality. This can be attributed to the high level of corruption and similar acts directed at non-financial FDI (which is included in the net FDI inflows to GDP) in African countries. FDI destined to agriculture and extractive mining in particular, bear the additional cost of paying kickbacks often demanded by government officials in exchange for protection from expropriation, notwithstanding the trade and capital openness of host countries. While Daude and Fratzscher (2008) affirmed the importance of strong regulatory institutions as a prerequisite for host nations to be able to attract FDI inflows, Kurul (2017) found that only countries that attain a certain threshold level of institutional quality are attractive to foreign direct investors.

We further find that there is a negative but statistically significant (at 5\%) relationship between FDI and the real exchange rate; a negative relationship between FDI and inflation, as well as FDI and the real interest rate, respectively. The negative signs were expected, based on prior empirical studies conducted by other scholars. The implications of these negative relationships is that FDI is shunned from host countries due an invariably unstable macroeconomic environment. Gumus, Duru and Gungor (2013) stated that a high exchange rate impacts on the profitability of shares of companies listed on the stock market, thereby further exposing foreign investors to exchange rate or currency risk.

With regard to FDI, openness is two-fold: capital openness, and trade openness. Capital openness was measured using the Chinn-Ito (2000) index. It is essentially the removal of restrictions of trade in international financial assets such as stocks and bonds globally. The results were expected to yield a positive sign, based on the presence of some countries in the panel study, which allow the free movement of money in and out of their financial markets; a general requirement to remain globally integrated with other markets. Similarly, the importance of trade openness for foreign 
direct investment cannot be downplayed. Foreign investors bring in not only capital destined for the stock market, but also invest in other physical, capital-intensive projects such as extractive mining and manufacturing, which require the importation and exportation of raw materials, by-products as well as finished goods. The relationship between foreign direct investment and trade openness, in the presence of stock market development, was found to be positive and highly significant at $1 \%$. This finding corroborates those reached by Alfaro et al. (2004); Soumaré and Tchana Tchana (2015), as well as Kurul (2017).

The lag of FDI, being the previous period's inflow of foreign portfolio investment, was determined to be positive and statistically significant in our study. This is supported by the existing proposition that prospective investors examine past trends of FDI, prior to making further financial commitments in foreign host countries, and is therefore an important predictor of current and future of FDI inflows to host countries (Makoni, 2016). In his endogenous growth model, Barro (1990) states that domestic economic growth and savings rates are affected by variations in the portion of productive government expenditure in GDP. In line with this, government spending was found to have a negative influence on FDI, as there is no guarantee to foreign investors that indeed funds circulating in the country are serving their intended purpose. Real GDP growth emerged as being an insignificant indicator of the performance of a host country's economy. FDI would not necessarily be affected by this, as that form of investment takes a long-term perspective, and it is therefore normal to expect cyclical economic cycles over a period of time (Sawalha et al., 2016).

This study thus supports the theoretical and empirical underpinnings that there is a positive and statistically significant relationship between FDI and stock market development, and a negative one between foreign direct investment and institutional quality, respectively. Hence, the more developed the stock markets become over time, the higher the likelihood of attracting inward FDI. On the other hand, poor institutional quality such as the reluctance to enforce contracts, not respecting property rights, corruption and bribery, amongst others, will tend to shun inward FDI as potential foreign investor confidence attitude towards such economies will be low.

\section{Conclusion}

According to several scholars, FDI is the most desired of all international capital flows, primarily due to its permanency. FDI complements the efforts of host country stock markets, by not only bringing in large amounts of capital onto the local equity markets, but also physical and non-financial capital in the form of skilled labour, and new technology. The $2007-2008$ global financial crisis affected many stock markets around the world, resulting in an outflow of FDI and other foreign capital flows back to the safety of their home countries. The ongoing Covid-19 global pandemic has also put FDI flows in the spotlight. This current study aimed to assess how African economies performed after the 2007 global economic meltdown, in terms of receiving inward FDI flows. We investigated the relationships between foreign direct investment, and stock market development as well as institutional quality, respectively. Under the random effects model, it was found that stock market development enjoys a positive relationship with FDI, while low institutional quality acts as a deterrent to inward FDI. These findings are supported by various theories and empirical studies, as discussed above.

Our paper makes a significant contribution in that it applies the Kunčič composite index for institutional quality. Kunčič's database gives different options of institutional quality measurements. The relative institutional quality values which range between -2 and 2, with a mean of zero (0); are calculated using factor analysis to identify latent factor scores for every country every year, within each institutional group. The absolute institutional quality measures, on the other hand, are simple averages of legal, political and economic institutional indicators within each group for within country analysis, which are transformed to the interval from zero to one. Kunčič (2014) argued that this permits the tracking of country dynamics, relative to other countries in the world, and in absolute terms. For the purposes of this study, we chose to adopt the absolute measures of institutional quality that allowed us to track the country dynamics.

The policy implications of our study are that governments of developing economies in Africa need to appreciate that while FDI is available and ready to flow to countries in the continent, there are minimum absorptive capacities that foreign investors expect to be in place prior to making large financial commitments in host countries. As such, the continuous development of stock markets should be a priority, which will promote the financial activities of both domestic and foreign firms alike. The stock markets further need to be complemented by strong positive institutions to ensure that the stock markets comply with internationally accepted practices of transparency and good governance. In addition, multinationals wish to operate on a level playing ground with domestic firms, insofar as the risk of expropriation are concerned. Macroeconomic variables such as the exchange rate need to be prudently managed to a certain extent. This, coupled with trade and capital openness, will see an increase in both imports and exports, 
without necessarily doing much damage to existing and future bilateral trade agreements such as the African Continental Free Trade Area (AfCFTA) agreement which seeks to boost intra-African trade among member states of the African Union. Policy makers should thus factor in these economic objectives into their macroeconomic policy formulation and implementation. FDI is complementary to the stock market, and provides a lower cost of capital than borrowing on other financial markets.

As per the arguments put forth above, foreign direct investments require stock market development in order for its economic spillovers to be absorbed. In the same vein, governments need to tread cautiously by not depending on FDI, which could potentially crowd out domestic savings and investments, as well as result in a mass exodus of capital from the country. Future studies could consider a comparative analysis of the pre- and post- global financial crisis international financial flows, as well as the effect of the application of the World Bank's world governance indicators vis-à-vis the Kuncic database of institutional factors, particularly to developing and emerging economies.

The findings of this study focused on a small sample of African countries, deemed to have the most development capital financial markets at the time. As such, the findings have limited generalisability as several other economic factors were excluded. As this topic is dynamic and ongoing, future studies could consider expanding the footprint and including stock markets of different sizes to assess whether the stock market development variable will yield different results when examined with FDI and institutional quality. In addition, comparative studies between developing African countries and emerging market economies in other parts of the world may serve interesting lessons for international finance scholars and policymakers alike.

\section{References}

Agbloyor, E. K., Abor, J., Adjasi, C. K. D., \& Yawson, A. (2013). Exploring the causality links between financial markets and foreign direct investment in Africa. Research in International Business and Finance, 28, 118-134. https://doi.org/10.1016/j.ribaf.2012.11.001

Alfaro, L., Chanda, A., Kalemli-Ozcan, S., \& Sayek, S. (2004). FDI and economic growth: the role of local financial markets. Journal of International Economics, 64(1), 89-112. https://doi.org/10.1016/S0022-1996(03)00081-3

Asiedu, E. (2006). Foreign direct investment in Africa: The role of natural resources, market size, government policy, institutions and political instability. The World Economy, 29(1), 63-77. https://doi.org/10.1111/j.1467-9701.2006.00758.x

Asiedu, E. (2013). Foreign direct investment, natural resources and institutions. International Growth Centre, Working Paper Series. Retrieved from https://www.theigc.org/wp-content/uploads/2014/09/Asiedu-2013-Working-Paper.pdf

Azman-Saini, W. N. W., Law, S. H., \& Ahmad, A. H. (2010). FDI and economic growth: New evidence on the role of financial markets. Economics letters, 107(2), 211-213. https://doi.org/10.1016/j.econlet.2010.01.027

Bailey, N. (2018). Exploring the relationship between institutional factors and FDI attractiveness: A meta-analytic review. International Business Review, 27(1), 139-148. https://doi.org/10.1016/j.ibusrev.2017.05.012

Barro, R. J. (1990). Government spending in a simple model of endogeneous growth. Journal of Political Economy, 98 (5, Part 2), S103-S125. https://doi.org/10.1086/261726

Bayar, Y., \& Gavriletea, M. D. (2018). Foreign direct investment inflows and financial development in Central and Eastern European Union countries: A panel cointegration and causality. International Journal of Financial Studies, 6(2), 55. https://doi.org/10.3390/ijfs6020055

Bekaert, G., \& Harvey, C. R. (2000). Foreign speculators and emerging equity markets. The Journal of Finance, 55(2), 565-613. https://doi.org/10.1111/0022-1082.00220

Bokpin, G. A., Mensah, L., \& Asamoah, M. E. (2015). Foreign direct investment and natural resources in Africa. Journal of Economic Studies, 42(4), 608-621. https://doi.org/10.1108/JES-01-2014-0023

Daude, C., \& Fratzscher, M. (2008). The pecking order of cross-border investment. Journal of International Economics, 74(1), 94-119. https://doi.org/10.1016/j.jinteco.2007.05.010

Donaubauer, J., Meyer, B., \& Nunnenkamp, P. (2016). Aid, infrastructure, and FDI: Assessing the transmission channel with a new index of infrastructure. World Development, 78, 230-245. https://doi.org/10.1016/j.worlddev.2015.10.015

Dorrucci, E., Meyer-Cirkel, A., \& Santabárbara, D. (2009). Domestic Financial Development in Emerging Economies: Evidence and Implications. European Central Bank (ECB) Occasional Paper No. 102. Retrieved 
from https://ssrn.com/abstract=1325243

Dunning, J. H. (1977). Trade, location of economic activity and the MNE: A search for an eclectic approach. In The international allocation of economic activity (pp. 395-418). Palgrave Macmillan, London. https://doi.org/10.1007/978-1-349-03196-2_38

Globerman, S., \& Shapiro, D. (2003). Governance infrastructure and US foreign direct investment. Journal of International Business Studies, 34(1), 19-39. https://doi.org/10.1057/palgrave.jibs.8400001

Goldsmith, R. W. (1969). Financial structure and development (No. HG174 G57).

Grosse, R., \& Trevino, L. J. (1996). Foreign direct investment in the United States: An analysis by country of origin. Journal of International Business Studies, 27(1), 139-155. https://doi.org/10.1057/palgrave.jibs.8490129

Gumus, G. K., Duru, A., \& Gungor, B. (2013). The relationship between foreign portfolio investment and macroeconomic variables. European Scientific Journal, 9(34), 209-226. Retrieved from https://core.ac.uk/download/pdf/328023929.pdf

Hajilee, M., \& Nasser, O. (2015). The Relationship between Financial Market Development and Foreign Direct Investment in Latin American Countries. The Journal of Developing Areas, 49(2), 227-245. Retrieved June 17, 2021, from http://www.jstor.org/stable/24241300

Haque, A., Patnaik, A. K., \& Hashmi, S. Z. (2017). Foreign direct investment and growth: A study in the context of Kuwait. International Journal of Financial Research, 8(1), 9-15. https://doi.org/10.5430/ijfr.v8n1p9

Humanicki, M., Kelm, R., \& Olszewski, K. (2017). Foreign Direct and Portfolio Investment in the Contemporary Globalized World: Should They Be Still Treated Separately?. Central European Journal of Economic Modelling and Econometrics, 9, 115-135. Retrieved from https://ssrn.com/abstract=3152381

Hymer, S. H. (1960). The international operations of national firms, a study of direct foreign investment. Doctoral thesis. Massachusetts Institute of Technology. http://hdl.handle.net/1721.1/27375

Islam, M. A., Khan, M. A., Popp, J., Sroka, W., \& Oláh, J. (2020). Financial development and foreign direct investment-The moderating role of quality institutions. Sustainability, 12(9), 3556. https://doi.org/10.3390/su12093556

Jensen, N. (2003). Democratic Governance and Multinational Corporations: Political Regimes and Inflows of Foreign Direct Investment. International Organization, 57(3), 587-616. Retrieved June 23, 2021, from http://www.jstor.org/stable/3594838

Kharabsheh, B., \& Aldaher, A. (2020). The Impact of Foreign Direct Investment on Financial Market Development: The Case of Jordan. International Journal of Financial Research, 11(4), 64-73. https://doi.org/10.5430/ijfr.v11n4p64

King, R. G. \& Levine, R. (1993). Financial intermediation and economic development. Capital Markets and Financial Intermediation, 156-189. Cambridge University Press.

Kiviet, J. F. (1995). On bias, inconsistency, and efficiency of various estimators in dynamic panel data models. Journal of Econometrics, 68(1), 53-78. https://doi.org/10.1016/0304-4076(94)01643-E

Kunčič, A. (2014). Institutional quality dataset. Journal of Institutional Economics, 10(1), 135-161. https://doi.org/10.1017/S1744137413000192

Kurul, Z. (2017). Nonlinear relationship between institutional factors and FDI flows: Dynamic panel threshold analysis. International Review of Economics \& Finance, 48, 148-160. https://doi.org/10.1016/j.iref.2016.12.002

Leamer, E. (1983). Let's Take the Con Out of Econometrics. The American Economic Review, 73(1), 31-43. Retrieved June 21, 2021, from http://www.jstor.org/stable/1803924

Lu, X., \& White, H. (2014). Robustness checks and robustness tests in applied economics. Journal of Econometrics, 178, 194-206. https://doi.org/10.1016/j.jeconom.2013.08.016

Makoni, P. L. (2020). Foreign Portfolio Investments, Exchange Rates and Capital Openness: A Panel Data Approach. International Journal of Economics \& Business Administration, 8(2), 100-113. https://doi.org/10.35808/ijeba/458

Makoni, P. L. R. (2016). The role of financial market development in foreign direct investment and foreign portfolio investment in selected African economies. Doctoral thesis, University of the Witwatersrand, Faculty of 
Commerce, Law and Management, Wits Business School). Retrieved from http://hdl.handle.net/10539/23720

McKinnon, R. I. (1973). Money and Capital in Economic Development. Washington D.C.: Brookings Institution.

North, D. C. (1990). A Transaction Cost Theory of Politics. Journal of Theoretical Politics, 2(4), $355-367$. https://doi.org/10.1177/0951692890002004001

OECD. (2021). FDI in figures: COVID-19 fallout sinks global FDI flows by 38\% in 2020. Retrieved 17 June 2021 , from https://www.oecd.org/investment/FDI-in-Figures-April-2021.pdf

Rajan, R. G., \& Zingales, L. (1998). Power in a Theory of the Firm. The Quarterly Journal of Economics, 113(2), 387-432. https://doi.org/10.1162/003355398555630

Ricardo, D. (1817). The works and correspondence of David Ricardo Vol. 1: On the principles of political economy and taxation.

Sarno, L., Tsiakas, I., \& Ulloa, B. (2016). What drives international portfolio flows?. Journal of International Money and Finance, 60, 53-72. https://doi.org/10.1016/j.jimonfin.2015.03.006

Sawalha, N., Elian, M., \& Suliman, A. (2016). Foreign capital inflows and economic growth in developed and emerging economies: a comparative analysis. The Journal of Developing Areas, 50(1), 237-256. Retrieved June 23, 2021, from http://www.jstor.org/stable/24737346

Schumpeter, J. (2017). Theory of Economic Development (1st ed.). Routledge. https://doi.org/10.4324/9781315135564

Shaw, E. S. (1973). Financial Deepening in Economic Development. New York: Oxford University Press.

Smith, A. (1776). The Wealth of Nations. Oxford University Press, Oxford.

Soumaré, I., \& Tchana Tchana, F. (2015). Causality between FDI and financial market development: Evidence from emerging markets. The World Bank Economic Review, 29(suppl_1), S205-S216. https://doi.org/10.1093/wber/lhv015

Stein, E., \& Daude, C. (2001). Institutions, integration and the location of foreign direct investment. OECD Global Forum on International Investment: New Horizons for Foreign Direct Investment, 101-130.

Van Bon, N. (2020). FDI and stock market development in developing countries: The role of governance environment. Chiang Mai University Journal of Economics, 24(2), 17-37. Retrieved June 17, 2021, from https://so01.tci-thaijo.org/index.php/CMJE/article/view/242766

Wei, Y., Zheng, N., Liu, X., \& Lu, J. (2014). Expanding to outward foreign direct investment or not? A multi-dimensional analysis of entry mode transformation of Chinese private exporting firms. International Business Review, 23(2), 356-370. https://doi.org/10.1016/j.ibusrev.2013.06.001

Wilhelms S. K. S., \& Witter, M. S. D. (1998). Foreign Direct Investment and its Determinants in Emerging Economies. African Economic Policy Paper 9. United States Agency for International Development Bureau for Africa, Office of Sustainable Development, Washington DC. Retrieved from http://www.eagerproject.com/discussion9.html

World Bank. (2017). Retrieved from https://data.worldbank.org/products/wdi

World Economic Forum (WEF). (2012). Financial development report - 2012. (Report). World Economic Forum. Retrieved from https://www.weforum.org/reports/financial-development-report-2012

World Investment Report. (2021). United Nations Conference on Trade and Development. World Investment Report 2021. Retrieved June 23, 2021, from https://unctad.org/system/files/official-document/wir2021_en.pdf

Yartey, C. A. (2010). The institutional and macroeconomic determinants of stock market development in emerging economies. Applied Financial Economics, 20(21), 1615-1625. https://doi.org/10.1080/09603107.2010.522519

\section{Copyrights}

Copyright for this article is retained by the author(s), with first publication rights granted to the journal.

This is an open-access article distributed under the terms and conditions of the Creative Commons Attribution license (http://creativecommons.org/licenses/by/4.0/). 